lawes among sundrie Nations, wee cannot bee assured of; but the law of God bindeth all men, and is without errour: and therefore also said David, That the testimonie of the law of God is faithfull: giuing wisedome to children.

\$8. Of the vnwritten law of God, giuen to the Patriarks by Tradition.

\$9. Of the Morall, Iudiciall, and Ceremoniall Law ...

\$10-1 2. A proposall of nine other points...

\$I 3. Of the seuerall Commandements of the Decalogue ...

\$14. If there were not any Religion nor Iudgement to come, yet the Decalogue were most necessarie to be obserued.

\$I 5. Of humane Law, written and vnwritten.

\$16. That only the Prince is exempt from humane lawes, and in what sort.

\title{
Ch. V. The Storie of the Israelites from the receiuing of the Law, to the death of Moses ${ }^{\mathrm{I}}$
}

\$10. Obseruations out of the Storie of Moses, how God disposeth both the smallest occasions, and the greatest resistances, to the effecting of his purpose.

I The single section from Chapter $v$, which follows, is directly related to the single one from Chapter xIx (below, p. 210). The titles of the intervening chapters are given to remind us of Ralegh's constant efforts to interlock the histories of Israel and other nations. 
Now let vs a little, for instruction, looke backe to the occasions of sundrie of the great euents, which have beene mentioned in this Storie of the life of Moses, for (excepting Gods miracles, his promise, and fore-choise of this people) hee wrought in all things else by the medium of mens affections, and naturall appetites. And so we shall find that the feare which Pharao had of the increase of the Hebrewes, multiplied by God to exceeding great numbers, was the next naturall cause of the sorrowes and losse, which befell himself, and the Egyptian Nation: which numbers when he sought by cruell and vngodly pollicies to cut off and lessen, as when he commanded all the male-children of the Hebrewes to be slaine, God (whose prouidence cannot bee resisted, nor his purposes preuented by all the foolish and saluage craft of mortall men) moued compassion in the heart of Pharao's owne Daughter, to preserue that child, which afterward became the most wise, and of all men the most gentle and milde, the most excellently learned in all Diuine and $\mathrm{Hu}$ mane knowledge, to be the Conductor and deliuerer of his oppressed Brethren, and the ouerthrow of Pharao, and all the flower of his Nation; euen then, when he sought by the strength of his men of Warre, of his Horse, and Chariots, to tread them vnder and burie them in the dust. The griefe which Moses conceiued of the iniuries, and of the violence offered to one of the Hebrewes in his owne presence, moued him to take reuenge of the Agyptian that offered it: the ingratitude of one of his owne Nation, by threatning him to discouer the slaughter of the Egyptian, moued him to flie into Midian: the contention betweene the sheep-heards of that place, and Iethro's Daughters, made him knowne to their Father: who not only entertained him, but married him to one of those Sisters: and in that solitarie life of keeping of his Father in lawes sheepe, farre from the presse of the world, contenting himselfe (though bred as a Kings Sonne) with the lot of a poore Heards-man, God found him out in that Desart, wherein he first suffered him to liue many yeares, the better to know the waies and passages through which he purposed that hee should conduct his people, toward the Land promised: and therein appearing vnto him, he made him know his Will and diuine Pleasure for his returne 
into Egypt. The like may be said of all things else, which Moses afterward by Gods direction performed in the Storie of Israel before remembred. There is not therefore the smallest accident, which may seeme vnto men as falling out by chance, and of no consequence: but that the same is caused by God to effect somewhat else by: yea, and oftentimes to effect things of the greatest worldly importance, either presently, or in many yeares after, when the occasions are either not considered, or forgotten.

Ch. VI. Of the Nations with whom the Israelites had dealing after their comming out of Agypt...

\section{Ch. VII. Of the Tribes of} Israel...

\section{Ch. VIII. Of the Kingdom of}

\section{Phonicia}

\section{Ch. IX. Of the Tribe of Ephraim ...}

